York University Press, 1967), 122. The second manuscript is "Assyria \& Egypt" in NUPM, 5:1927-1928, which contains notes headed "Greeks," "Romans," "?India," and "Hebrews." The notes closely parallel the ideas put forth in the newspaper clipping on the current manuscript, suggesting that Whitman was paraphrasing ideas he didn't share. Such cases should serve as a caution against assuming that Whitman's notes always express his own earnest beliefs.

\title{
JOHN BUTLER YEATS AND JACK B. YEATS ON WHITMAN
}

From time to time, some new bit of information turns up that sheds light on those annual Whitman dinners organized to honor the poet's birth. Of those that took place during Whitman's lifetime we have a good knowledge, largely owing to the sterling efforts of Horace Traubel, but of those that occurred in the early years of the twentieth century we are still discovering bits and pieces, some of which lead to unsuspected treasures. One such piece can be found in Letters to W. B. Yeats where, in a letter from William Butler Yeats's father John Butler Yeats (1839-1922) written from New York on May 27, 1913, we learn that John Butler Yeats would not only attend that year's Whitman dinner but would make a speech. The latter privilege he deemed "a mixed joy" since he viewed the attendees as "people the most remote from art and literature," and as "all mad-in an amicable sort of way." But if "a fire-brand" were thrown among them "in the shape of a blood-and-thunder speech," he claimed, their amicability vanished. Further, he believed they suffered from "the same lunacy" in their literal interpretation of Whitman's writings as was manifested in earlier readings of the Bible. ${ }^{1}$ While no record of his speech exists, it is possible to gain some idea of its general import and to imagine the effect of Yeats's characteristically straightforward, "pull-no-punches" style of delivery on the assembled Whitmanites.

John Butler Yeats was an artist of considerable reputation in his native Ireland when he came to New York in 1907, largely at the urging of John Quinn, who functioned as patron and friend to many artists of the time. Quinn (1870 -1924), born in Ohio, led a fascinating life: he was assistant to the secretary of the U.S. Treasury before joining (on the strength of his Harvard law degree) a prestigious New York law firm in 1900. His interests were art, literature (he was a great friend to Ezra Pound and James Joyce), and all things Irish. He developed a passion for paintings, among others those of John Butler Yeats, from whom he commissioned portraits of prominent Irish figures. ${ }^{2}$ Quinn's correspondence with the artist lasted for years, widening to include William Butler Yeats, and Quinn helped both father and son further their careers in America. When John Butler Yeats came to New York, Quinn, very much a man about town, saw to it that the painter met everyone he would have liked. Among these was John Burroughs, who attended a lunch at the Players Club, where Quinn and Yeats were feted. ${ }^{3}$ In the days following the lunch, Yeats remarked to others that people regarded Burroughs as another Walt Whitman. With Quinn to introduce him, Yeats, a voluble and witty man, soon became known in New York as much for his skills as an after-dinner speaker as for his paintings. It was not long before he was also writing essays for magazines. 
We can gain some indication of the "firebrand" Yeats no doubt threw at attendees of the 1913 Whitman dinner from letters he wrote to Quinn a year later when he was working out some ideas on Whitman, which he planned to develop into an essay. Van Wyck Brooks was to help him place the essay with Maxwell Perkins, the Scribner's editor who later became famous for his work with F. Scott Fitzgerald (Yeats's ulterior motive in approaching Perkins was supposedly to secure a commission to create a portrait of Perkins's mother). ${ }^{4}$ According to a Yeats letter to Quinn, his essay set out to expose Whitman as a dangerous model for Americans because of the purely emotional cast of his poetry, which Yeats believed Americans, already too highly emotional, should not idealize. Drawing a distinction between emotion and feeling (the latter being, to his mind, sterner stuff, "more allied to pain than to pleasure"), he contrasts such men as Milton and Dante with Whitman and finds in Whitman "something unbraced and relaxed." "To his son, William Butler Yeats, he wrote a short time later that, Americans everywhere "led by their women kind are leading the surface life with an absolute intensity," a condition that he believed certain of their poets had taken up, among them Pound and Whitman, but, he added, Pound, unlike Whitman, "degrades" the

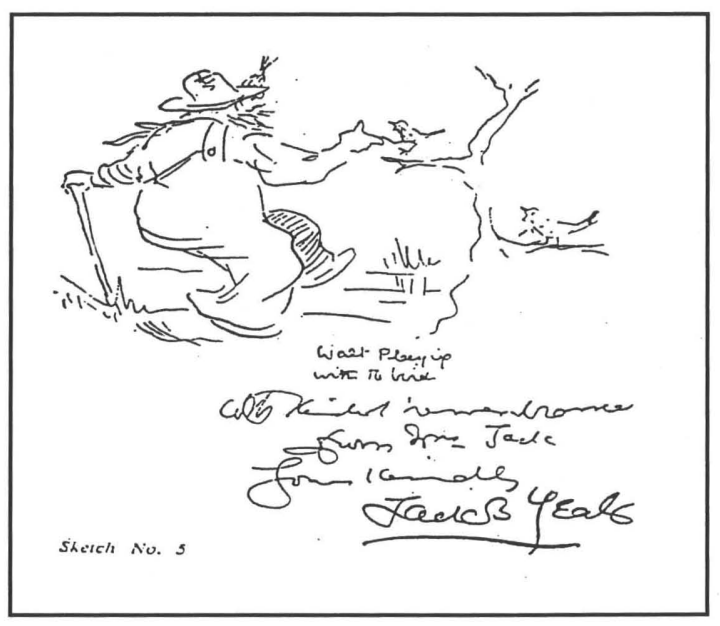

Figure 1.

surface life, "showing it to be unworthy." "Yeats is obviously responding to something he sees (or feels?) as loosely feminine in Whitman's works, "something unbraced and relaxed," as he put it to Quinn.

John Butler Yeats died in New York in 1922, having been cared for in his final illness by John Quinn, and was buried in Chestertown, New York, a small town in the Adirondack Mountains, in the family plot of a friend. Another of his sons, Jack B. Yeats, a painter like his father, offers a final Whitman connection that is considerably kinder to the poet than his father's judgment. In August 1960 a friend of Jack B. Yeats, Arnold Harvey, published some of Yeats's sketches that had been included in letters sent by the artist to Harvey. Though he does not date the works, he claims they belong to a time before Yeats took up oil painting, when "he went about the world notebook in hand in search of the exuberant, the extravagant, the uninhibited and the naive in the human scene, wherever it was to be found." In fact, Jack B. Yeats did not travel the world but found most of his examples, as he did his inspiration, in Ireland's west country. Surprisingly, one of the sketches Harvey offers is of Walt Whitman (see Figure 1), looking as he might have during one of his extended visits with the Stafford family in southern New Jersey in the years 1876 and 1884 . Of the drawing Harvey writes, "In the field of literature Jack 
Yeats found the quality of exuberance in the figure of Walt Whitman, that most exuberant of poets, and I am fortunate in being able to illustrate my thesis with his sketch of a modern, secular St. Francis, whose poetry he has been reading as a pillow book, playing with the birds." 7

Hofstra University

JOANN P. KRIEG

\section{NOTES}

1 Letters to W. B. Yeats, ed. Richard J. Finneran, George Mills Harper, and William M. Murphy (New York: Columbia University Press, 1977), 1:96, 267.

2 The best source on Quinn is B. L. Reid, The Man from New York: fohn Quinn and His Friends (New York: Oxford University Press, 1968).

3 Finneran et al., 1:330.

4 Finneran et al., 1:312.

5 Yeats to Quinn, May 5, 1914; quoted in Finneran et al., 1:312.

6 Finneran et al., 1:427.

7 "Sketches from Letters by Jack B. Yeats," The Irish Times (August 24, 1960), 8.

\section{THE FIRST PUBLICATION OF GRACE ELLERY CHANNING'S TRIBUTE TO WHITMAN}

As Joann P. Krieg has recently noted, Grace Ellery Channing's “connections to the world of nineteenth-century literature and to Whitman" merit more attention than they have hitherto received. ${ }^{1}$ The granddaughter of William Ellery Channing, the niece of William Douglas O'Connor, as well as a close friend of and occasional collaborator with Charlotte Perkins Stetson (Gilman), Channing earned a modest reputation as a poet in her own right. She is perhaps best known today, however, as Charlotte Perkins Gilman's "co-mother" after she married the artist Charles Walter Stetson, Gilman's former husband, in 1894. Though O'Connor had offered Charlotte a copy of Leaves of Grass as early as 1883 , she had been "obliged to decline" the gift because she "had promised Walter I would not read it." "I did not want her to think all men such animals as Whitman described them," as Stetson noted in his diary. ${ }^{3}$

Ironically, as the poem reprinted below suggests, Grace Channing, Stetson's second wife, championed the genius of Whitman, her uncle's friend. Channing apparently persuaded Charlotte to read Whitman after she ended her marriage to Stetson in 1890 and moved to Pasadena to live near the Channings. In any event, Charlotte soon began to quote such verses as "Beginners" and "Song of Myself" in her lectures, and as early as February 1891 she hailed Whitman as "America's greatest poet." Near the end of her life, in fact, Charlotte publicly declared that Whitman had been one of "our two greatest Americans."

The first publication of Channing's poem "Walt Whitman" in the Boston Transcript for September 10, 1892, narrows its date of composition to the first 